【論文】

UDC : $691.32: 666.97: 620.178 .3$
日本建築学会構造系論文報告集 第 428 号・1991 年 10 月 Journal of Struct. Constr. Engng, AIJ, No.428, Oct., 1991

\title{
コンクリート梁の切欠き有無による曲げ疲労強度と亀裂進展速度 FLEXURAL FATIGUE STRENGTH AND CRACK GROWTH IN CONCRETE BEAMS WITH NOTCH OR UNNOTCH
}

\author{
金子林爾*,大岸佐吉** \\ Rin̈i KANEKO and Sakichi OHGISHI
}

\begin{abstract}
Experimental investigations on flexural fatigue strength and crack growth in plain concrete beam with notch or unnotch were conducted by means of four-points bending test method. These tests were carried out under the following condition, a) size of concrete beam; $75 \times 75 \times 300 \mathrm{~mm}$, b) single edge notch beam with relative notch depth; 0.12 constant, c) cyclic load at $5 \mathrm{~Hz}$, d) repeated maximum load rates; $0.8,0.75,0.7$ and 0.65 , e) load amplitude; $0.1,0.25,0.5$ and 0.75 . According to test results, the conclusions were obtained as follows; 1 ) flexural fatigue strength in notched beam can be explained by equation of $S_{\max }=0.839-0.052 \cdot \log N_{f}, 2$ ) flexural fatigue strength of notched beam is about $10 \%$ smaller than one of the unnotched beam, 3) in range of strain softening zone, Paris' low can be applied for concrete, 4) material constant, $\mathrm{m}$ in Paris' low showed by $(d a / d N)=C(\Delta k)^{m}$, is $4.2 \sim 4.9$ for concrete.
\end{abstract}

Keywords : concrete beams, four-point bending test, flexural fatigue strength, stress intensity factor, crack growth

コンクリート梁, 4 点曲げ試験, 曲げ疲労強度, 応力搪大係数, 亀裂進展

\section{1.はじめに}

コンクリートの絽返し疲労に対する強度と寿命との関 係は，旧来では単に強度のばらつきを考慮にいれた数理 的表現による場合が多く，また繰り返しの途中に生ずる 微視的な経過現象を無視することが多かった。しかし， コンクリートのような脆性挙動を示す材料では, 組織が 極めて複雑な内部構造を持つごとからみて, 従来の強度 のみに基づく破壊論では適切な破壊過程を記述すること はできない。したがって，コンクリートは金属やガラス など脆性材料之同様に, 内部欠陥の存在および亀裂の成 長が予測されることを考慮した破壊力学的な手法を，疲 労問題に取り入れる必要がある。

コンクリートの破壊勒性の評価は Kaplan"1によって 着手されて以来, 多くの研究 ${ }^{21-8)}$ が行われたが, いまだ コンクリートの繰返し疲労問題に適用した研究例 91 .101 は 非常に少ない。コンクリートの繰返し疲労においては, 潜在的な龟裂あるいは切欠き部に生ずる亀裂がゼのよう に成長して破壊に至るかを解明することは極めて重要で ある。つまり，亀裂をもつ部材の強度評価と亀裂進展挙 動の把握が大切であろう。繰返し疲労に影響する因子と
して,コンクリート用材料, 調合, 試料寸法, 静的強度, 切欠きの形状とその深さ比, 環境条件, 載荷方法, 繰返 し応力度の上下限值, 繰返し速度, 載荷波形の種類など 多くの事項が挙げられる。

本研究は，コンクリート梁の曲げ度労特性を明らかに することを目的とし，同一調合，同一寸法の梁について 疲労寿命に及ぼす切欠きの有無と疲労応力の上下限值の 影響を実験的に調べた。また，破壊までの繰返し回数と 引張縁ひずみの増大変化, 切欠き部の開口変位に基づく 亀裂進展の状況, 繰返し疲労による亀裂進展速度と応力 拡大係数との関係を各応力段階について検討することを 試みた。

\section{2. 実験方法}

\section{1 切欠き材と平滑材の供試体作製}

本実験に用いたコンクリートは, 普通ポルトランドセ メント（比重 3.14, 材令 28 日压縮強度 $42.1 \mathrm{MPa}$ ), 細骨材 (山砂, 比重 2.51, f. m. $=2.92$ ) 之粗骨材 (山砂 利, 比重 $2.59, \mathrm{f} . \mathrm{m} .=7.23)$ を使用した。単位コンクリー トの重量調合はセメント $2.94 \mathrm{kN} / \mathrm{m}^{3}$, 水 $1.61 \mathrm{kN} / \mathrm{m}^{3}$,
*·名城大学理工学部建築学科 助教授

** 名古屋工業大学社会開発工学科 教授 $\cdot$ 工博
Assoc. Prof., Dept. of Architecture, Faculty of Science and Engineering, Univ. of Meijo.

Prof., Dept. of Architecture and Civil Engineering, Nagoya Institute of Technology, Dr. Eng. 


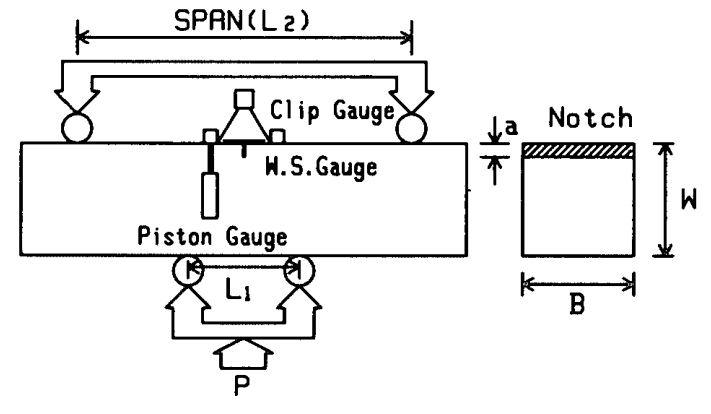

図一1 載荷方法と供試体の変位測定

砂 $7.48 \mathrm{kN} / \mathrm{m}^{3}$, 砂利 $10.0 \mathrm{kN} / \mathrm{m}^{3}$ であり, 水セメント 比 $55 \%$, 細骨材率 $43.4 \%$; AE 減水剂（セメント重量 に対して $0.2 \%$ ）を使用した。コンクリートの練り混ぜ は，可傾式ミキサー（容量 100 リッター）によった。実

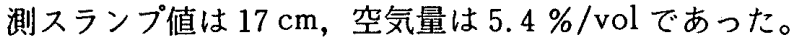

供試体の寸法は $75 \times 75 \times 300 \mathrm{~mm}$ の角柱体である。切 欠きのある供試体の作製には, 型枠側面に幅 $9 \mathrm{~mm}$, 厚 み $0.4 \mathrm{~mm}$ のステンレス製カッター刃を取り付けて切欠 きを設けた。このステンレス製カッター刃を用いた理由 は, 切欠き先端半径を限りなく小さくし, 理想亀裂に類 似するように鋭い切欠きを与えることを考虑したためで ある。切欠き材の相対切欠き深さ比を（ $a / W=0.12 ）$ に一定とした。切欠きのない平滑材では，この刃を用い なかった。ここに，Wは梁の高さ， $a$ は切欠き深さを 表す。

供試体は，すべて材令 28 日まで水中養生とし，それ 以後室内養生 $\left(20^{\circ} \mathrm{C}, \mathrm{RH}=60 \%\right)$ とした。室内保存中 の供試体の水分損失の時間曲線を実測し，もはや大きな 重量減少を認めなくなった時点の材令 56 日以後を試験 材令とした。試料は気乾状態である。

\section{2 試験装置と試験方法}

静的曲げ強度試験および曲げ疲労試験共に，電気油圧 式サーボバルブ機構の材料試験装置（MTS 社製 810-13 型, 最大荷重 $25 \mathrm{t}, 12.5 \mathrm{t}, 5 \mathrm{t}, 2.5 \mathrm{t}$ の 4 段切り替え可 能）を使用した。曲げ疲労の載荷は 5 サイクル/秒とし た。荷重波形は正弦波である。曲げ供試体の載荷要領と, ひずみ測定および変位测定の概念を図一1に示す。

疲労載荷下の曲げ供試体の引張縁ひずみは，梁中央の 引張縁に貼ったワイヤーストレンゲージ (測長 $60 \mathrm{~mm}$ ) により測定し，また切欠き部の開口変位 (Crack Opening Displacement, COD) は切欠き部を中心として内法 $12 \mathrm{~mm}$ の間隔でステンレス製ハ夕金を 2 個供試体に固 定し，この金具に取り付けたクリップ型変位計(MTS 社製 $632.13 \mathrm{C}-20)$ により測定した。他方, 梁中央部の たわみ変形の測定にはキャンチレバ（ピストン）型変位 計（TS 社製，CDP-25）を使用した。これら測定計の 出力データはすべて 7 チャンネル・アナログ入カイン ターフェイス (YHP 製 98640 A) を介して, デスクトッ プ・コンピュータ（YHP 社製 $9826 \mathrm{~A}$ ) により集録し,
表一1 切欠き材と平滑材の疲労試験条件と試料数

\begin{tabular}{|l|cccc|c|}
\hline Specimen & \multicolumn{4}{|c|}{ Notched } & Unnotched \\
\hline Smax $R$ & 0.1 & 0.25 & 0.5 & 0.75 & 0.1 \\
\hline 0.8 & 6 & - & - & - & 5 \\
0.75 & 6 & 6 & 4 & 4 & 6 \\
0.7 & 6 & 4 & 5 & - & 5 \\
0.65 & 6 & - & - & - & - \\
\hline
\end{tabular}

$S_{\max }=\sigma_{\max } / \mathrm{Fb}, S_{\max }$ :Maximum stress $r$ atio, $\mathrm{Fb}:$ Mean value of flexural strength(MPa), R=Smin/Smax

かつデータ処理を行った。

\section{3 静的および疲労曲げ試験方法}

切欠き材と平滑材はともに，静的曲げ強度および曲げ 疲労試験は 4 点曲げ方式（図一1参照）で荷重を加え, 切久きの形状は先述のごとく, SEN (Single Edge Notched) はり供試体で行った。

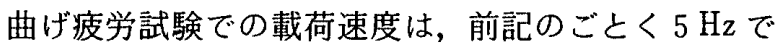
ある。 $5 \mathrm{~Hz}$ 選定の理由は, Kesler ${ }^{11)}$ の曲げ疲労試験に よれば載荷速度が $1.2 \mathrm{~Hz}$ と $7.3 \mathrm{~Hz}$ では結果にほとんど 差がないとの報告に基づき定めた。繰返し応力は疲労試 験開始時点の静的曲げ強度の平均值 $\left(F_{b}\right)$ を基準とし, これに対する上限応力比 $\left(S_{\max }=\sigma_{\max } / F_{0}\right)$ と上下限応 力比 $\left(R=S_{\min } / S_{\max }\right)$ の組合せを表一1のように選ん で実施した。すなわち, 曲げ疲労試験の設定応力の範囲 は, 切欠き材では, $S_{\max }=0.8,0.75,0.7,0.65$ とし, $R=0.1 ， 0.25,0.5,0.75$ の組合せのうち, 表一1に示 すように 9 種類の載荷条件について実験した。他方, 平 滑材では, $S_{\max }=0.8,0.75,0.7$ で $R=0.1$ だけにつ いて実験した。表一1 中の数值は供試体の個数を表す。

\section{4 破壊パラメータの測定方法}

刍裂をもつ供試体に曲げ応力が作用するとき，亀裂先

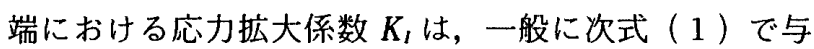
えられる。

$$
K_{l}=\sigma \cdot \sqrt{a} \cdot Y
$$

本実験での SEN(Single Edge Notched)梁では, 式( 1 ) の $K$, の値は，夷測の $\sigma$ の值を用いて式（2）で算定し た。同式中の $Y$ は, 試験片の形状と試験方法で定まる 係数であり, Srawley ${ }^{12)}$ の解析値, 式 (3) により得ら れる。

$$
\begin{aligned}
& \sigma=\frac{3 P\left(L_{2}-L_{1}\right)}{2 B W^{2}} \text {. } \\
& Y=1.99-2.47 \alpha+12.97 \alpha^{2}-23.17 \alpha^{3} \\
& +24.8 \alpha^{4} \text {. }
\end{aligned}
$$

ここに, $\alpha=a / W, P$ : 荷重 $(N), L_{2}$ : 支点間距離 $(225 \mathrm{~mm}), L_{1}$ : 荷重点間距離 $(75 \mathrm{~mm}), a$ : 亀裂長さ $(9 \mathrm{~mm}), W$ : 供試体高さ $(75 \mathrm{~mm}), B$ : 供試体幅 (75 mm) である（図一1 参照)。 


\section{3. 実験結果と考察}

3.1 静的曲げ強度および曲げ疲労試験結果

疲労試験の作用荷重を決定するにあたり，切欠き付き 供試体 6 個の静的曲げ試験結果より，曲げ強度の平均值 が $F_{b}=5.83 \mathrm{MPa}$ であることと, その標準偏差が $s_{d}=$ $0.366 \mathrm{MPa}$ であることを得た。他方，平滑材 6 個につ いて同様に $F_{b}=6.07 \mathrm{MPa} と s_{d}=0.248 \mathrm{MPa}$ を得た。 この結果, $a / W=0.12$ の切久き材の曲げ強度は, 平滑 材のそれよりも約 $4 \%$ 低く; また強度のばらつきも大 きい。これは先鋭な亀裂が，強度に敏感に影響したため と考えられる。

\section{2 切欠き材と平滑材との $S-N$ 関係}

切欠き材について，上下限応力比が $R=0.1$ の場合に， 上限応力比が $S_{\max }=0.8 \sim 0.65$ 間での 4 段階について 試験した破壊までの繰返し回数 $\left(N_{f}\right)$ の対数平均値の 結果を図一2に示す。同様に平滑材についての結果を図 -3に示す。この両図における各応力段階での疲労破壊 回数の対数平均值 $\left(\log N_{f}\right)$ を最小 2 乗法により回帰式 の係数を決定すると次の二式を得る。本論文では, log $N$ とは $\log _{10} N$ を意味する。

切欠き材の場合, $S_{\max }=0.839-0.052 \cdot \log N_{f}(4)$

平滑材の場合, $S_{\max }=0.89-0.051 \cdot \log N_{f} \cdots \cdots$ ( 5 )

上の二式から, 繰返し回数 200 万個の疲労強度は, 切 欠き材と平滑材では，それぞれ 0.512 と 0.569 が得られ

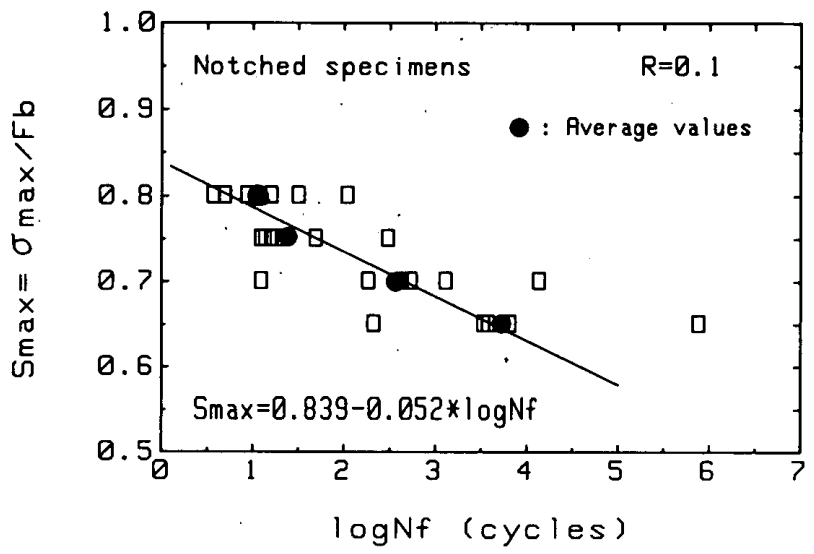

図一2 切欠き材の上限応力比之疲労破壊回数

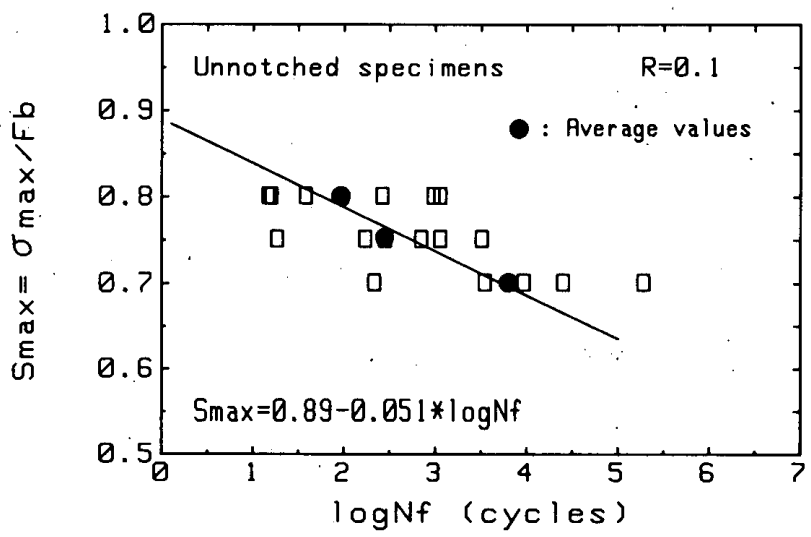

図一3 平滑材の上限応力比と疲労破壊回数
た。いま疲労強度の低下の程度を表す係数として, 平滑 材の疲労強度 $\left(S_{u}\right)$ に対する切欠き材の疲労強度 $\left(S_{n}\right)$ の比を切欠き係数 $(\beta)$ として表すと,

$$
\beta=\frac{S_{n}}{S_{u}}
$$

本実験では両者の比は， $\beta=0.90$ が得られる。つまり相 対切欠き深さ $a / W=0.12$ の切欠き材は平滑材の疲労強 度よりも約 $10 \%$ 低下することを知る。

切久き材の疲労試験の結果から， $S_{\max }$ と $\log N_{f}$ との 関係を $R=0.1 ， 0.25,0.5$ の 3 つの荷重振幅段階別に 示したものが図一 4 である。ただし， $R=0.25 ; 0.5$ の 場合は, $S_{\max }=0.75,0.7$ の 2 水準である。各応力比ご とに回帰式を求めると， $R=0.1$ のときは上記の式 $(4)$ で, $R=0.25$ と $R=0.5$ の場合は式 $(7)$ と式 (8) で それぞれ示される。

$$
\begin{aligned}
& R=0.25 \text { のとき, } S_{\max }=0.863-0.04 \cdot \log N_{f} \cdots(7) \\
& R=0.5 \text { のとき, } S_{\max }=0.898-0.044 \cdot \log N_{f} \cdots(8)
\end{aligned}
$$

この結果, 作用する応力比を等間隔で変化させても回帰 式の切片と勾配は， $R$ に必ずしも比例して変化しない。 しかし，図一4に認められるように，疲労寿命は応力振 幅の大きい $R=0.1$ の場合が，他の $R$ の值の場合より も疲労強度を最も低下させることがわかる。すなわち， 応力振幅は明らかに曲げ疲労寿命に影響する。

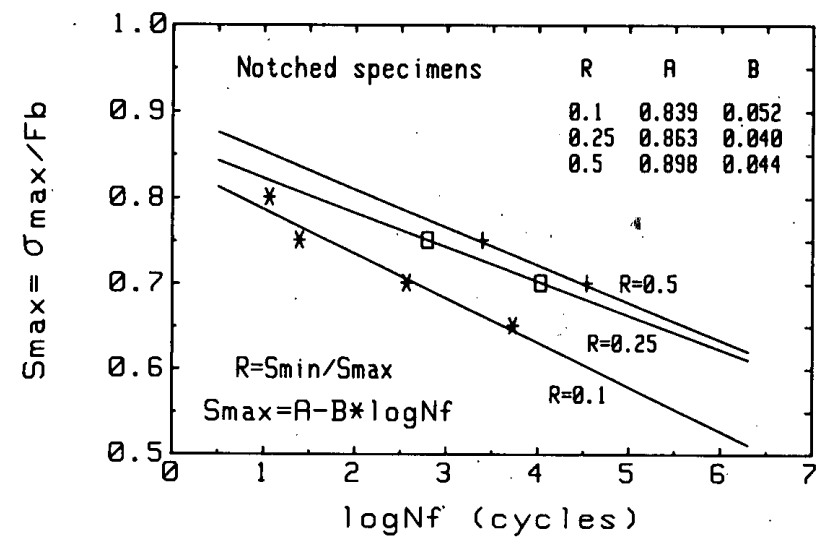

図一4 切欠き材の上限応力比と疲労破壊回数

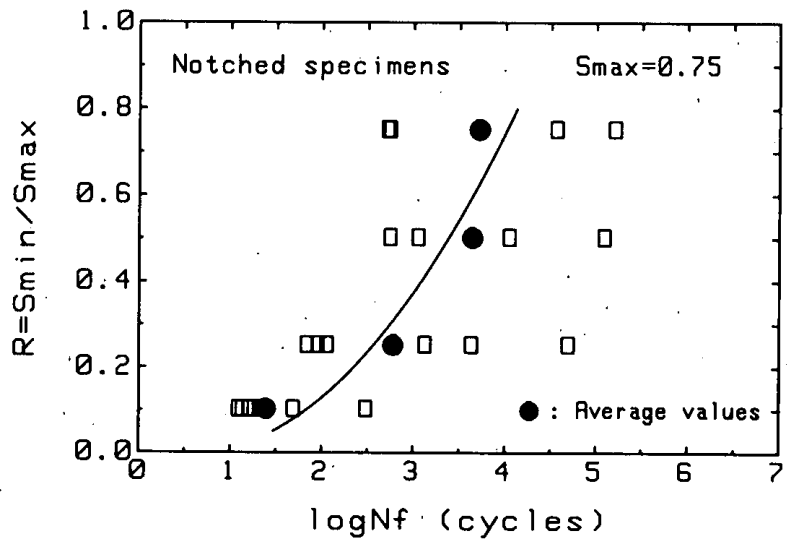

図一5 上下限応力比之疲労破壊回数 


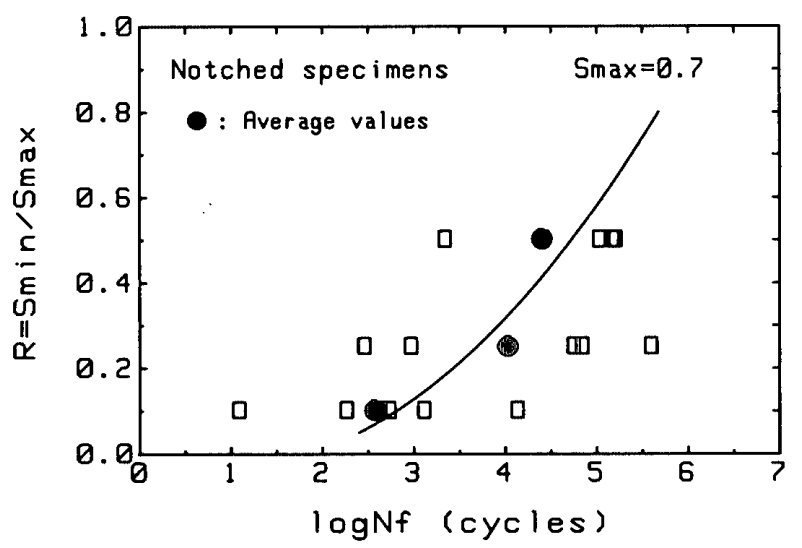

图一 6 上下限応力比之疲労破壊回数

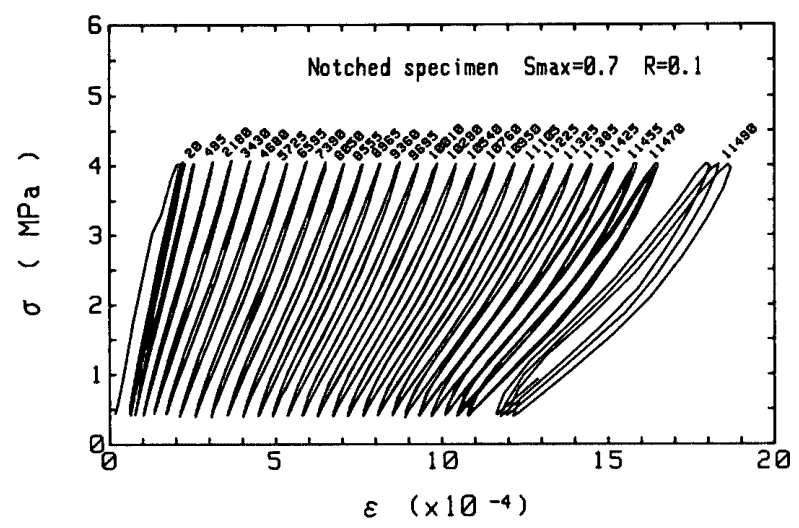

图一7繰返し応力と引張縁ひす み

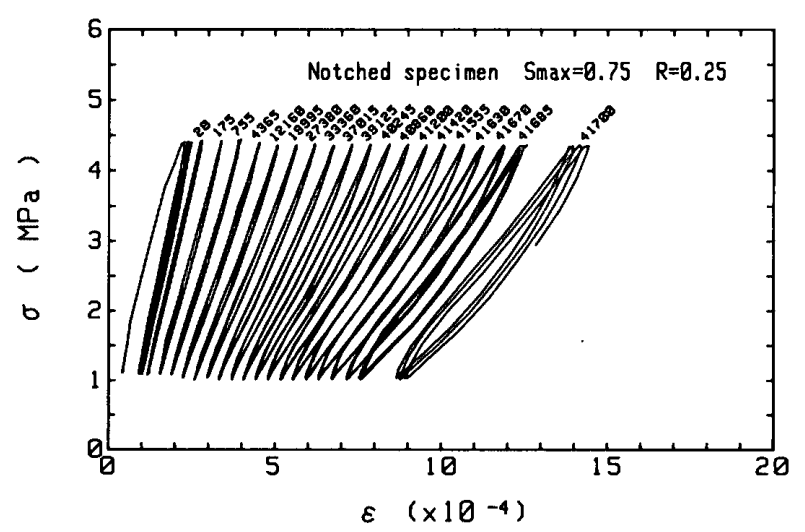

図一8 繰返し応力と引張緣ひずみ

\section{3 切欠き材の $R-N$ 関係}

切欠き材について, $S_{\max }=0.75$ 一定の場合, $R=0.1$, $0.25,0.5,0.75$ の 4 段階での疲労破壊回数亡疲労強度 の関係を図一 5 に示す。同じく切欠き材で $S_{\max }=0.7$ 定下で， $R=0.1 ， 0.25 ， 0.5$ の 3 段階における疲労破 壊回数との関係を図一6に示す。これら両図から， $S_{\max }$ が一定の場合， $R$ の値が大きくなるにつれて疲労寿命 も大きくなり，べき乗の曲線を示す傾向がみられる。 $S_{\max }=0.75$ と 0.7 では, この曲線の曲率は $S_{\max }$ が小さ くなるにつれて小さくなる。 $R=1.0$ は応力振幅のない 静的曲げクリープ武験に相当する。

\section{4 繰返し疲労下の引張縁ひずみの挙動}

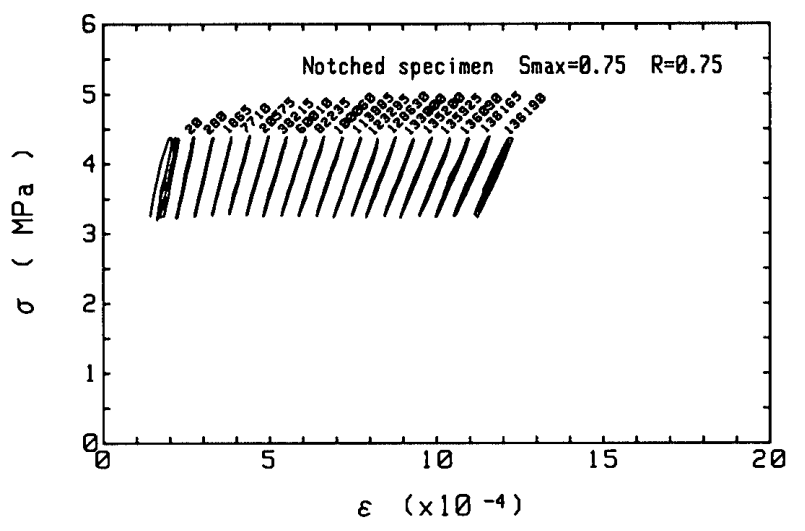

图一9 繰返し応力と引張縁ひずみ

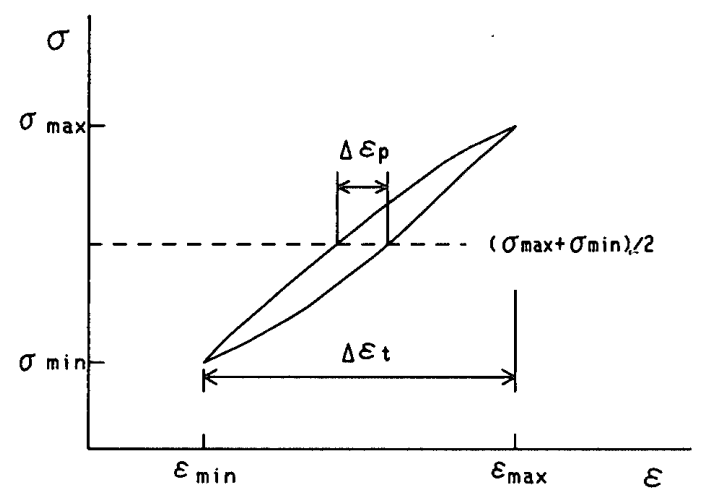

図一10 $\Delta \varepsilon \tau$ と $\Delta \varepsilon \rho$ の定義

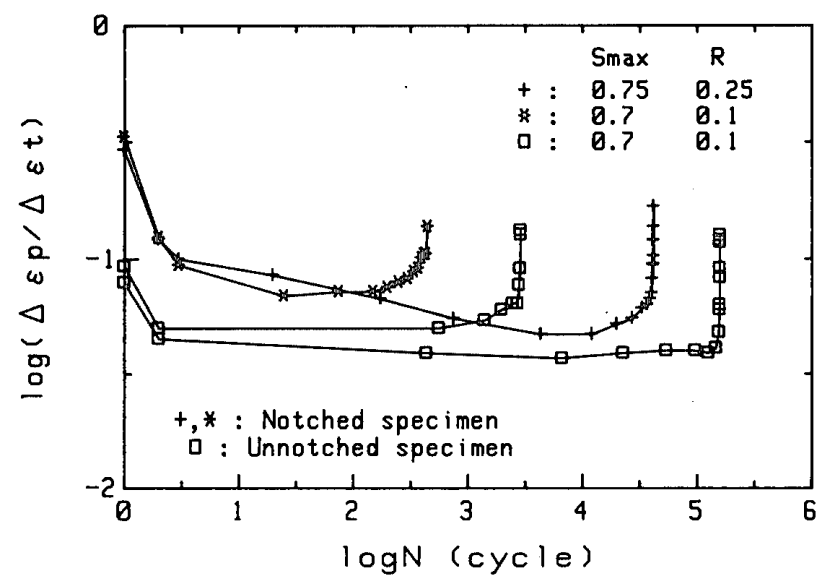

图一11繰返しごとの引張縁ひずみ変化

荷重振幅を異にする繰返し応力下の引張縁ひずみの履 歴曲線の例を図一7－図一9に示す。図ー10のループの 面積は熱消費エネルギーと理解され, 亀裂の成長と関係 があると考えられる。図ー11 は，図-10の説明図に示 すようにコンクリート梁の繰返し回数 $(N)$ と，下限応 力 $\left(\sigma_{\min }\right)$ から上限応力 $\left(\sigma_{\max }\right)$ までの応力の範囲内で 繰り返される引張縁ひずみ幅 $\left(\Delta \varepsilon_{t}\right)$ と応力点 $\left(\sigma_{\max }+\right.$ $\left.\sigma_{\mathrm{min}}\right) / 2$ での塑性ひずみ幅 $\left(\Delta \varepsilon_{\rho}\right)$ の比を切欠き有無の 両者の関係の例を示す。この図にみるごとく，ひずみ比 $\left(\Delta \varepsilon_{p} / \Delta \varepsilon_{t}\right)$ の変化は, 平滑材では繰返し回数 $(N)$ が 2 回目以降, $\log N$ が増しても微小であり, 破壊の間際 で急激に増大する。他方，切欠き材では繰返し回数が 2 
回目以後, 除々に漸減し, ある極小值に達する。これを 過ぎると繰返し回数の増加とともにこの比は漸増し, や がて破壊の直前において急増する。繰返し回数に対する $\left(\Delta \varepsilon_{p} / \Delta \varepsilon_{t}\right)$ の娍少勾配が初期の段階で大きいほざ, 疲 労寿命は短くなる傾向がある。破断近傍でのこの比の漸 増現象は, ひずみが引張軟化域に達していることを示す ものであろう。

平滑材の初回のひずみは切欠き材のそれよりも小さ い。これは引張縁ひずみが切欠き材において，亀裂先端 に応力が集中し，それに伴ってひずみを増すが，平滑材 では亀裂の近くに存在している多くの空孔や多数の微細 ひび割れが亀裂の発生源となり，ひずみ増加がある領域 に分散するためと考えられる。

\section{5 疲労下の引張縁ひずみおよび開口変位と亀裂進展 挙動}

繰返し応力下における引張縁ひずみ $(\varepsilon)$ と切欠き部 の開口変位 $(\delta)$ との関係を明らかにするため, 一定の ひずみ増加ごとに各繰返し上限応力下でのひずみ量 $\left(\varepsilon_{\max }\right)$ と変位量 $\left(\delta_{\max }\right)$ の実測関係を 5 つのケースに ついて示したものが図一12である。この図によれば, $R \geqq 0.25$ では，両者は繰り返しの初期から破壊に至る まで直線状を示し比例関係を持続する。しかし， $R=$ 0.1 では, 両者は比例関係を示さず, 引張縁ひずみに比 ベて開口変位の増加が少ない挙動を示した。このことは, $\varepsilon$ と $\delta$ の関係は応力振幅 $(R)$ の大小によって引張縁ひ ずみの累積・成長と開口変位の亀裂・伝播が異なること を示すものであろう。

繰返し応力下での回数が増すと, 亀裂の発生と成長を 生ずるが, 疲労破壊までの繰返し回数と開口変位との関 係の一例を図一13 に示す。

適用した繰这し上下限の応力範囲に対応する引張縁ひ ずみ振幅 $\left(\Delta \varepsilon=\varepsilon_{\max }-\varepsilon_{\min }\right)$ および開口変位の振幅 $(\Delta \delta$ $\left.=\delta_{\max }-\delta_{\min }\right)$ が破壊までに，よ゙のように変化するかを 図一14 に示す。この図から， $\Delta \varepsilon$ は絽返し回数の増大に

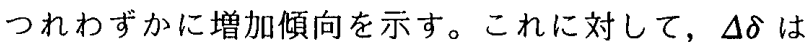
$\log N$ に対して途中に停滞するところがあり， $\Delta \delta$ の増 大変化は滑らかではない。これは亀裂進展による開口変 位が繰返し回数に対して必ずしも連続的に漸增しないこ とを示している。

亀裂進展を目視で知ることは精度的に不適切である が，供試体表面の観察による限りでは，切欠き部からの 亀裂進展は繰返し回数の増加に対して比例的に進展する ことはなく, 目視できる範囲で亀裂は停滞することが観 察され，次の段階で急に刍裂が生成することが認められ た。すなわち，亀裂は常に連続的に成長するとは限らず， 突発的に伝播することがある。

切欠き先端の亀裂の成長は疲労の初回では極めて遅 く,さらに疲労回数が増して,ひずみが軟化域に達する

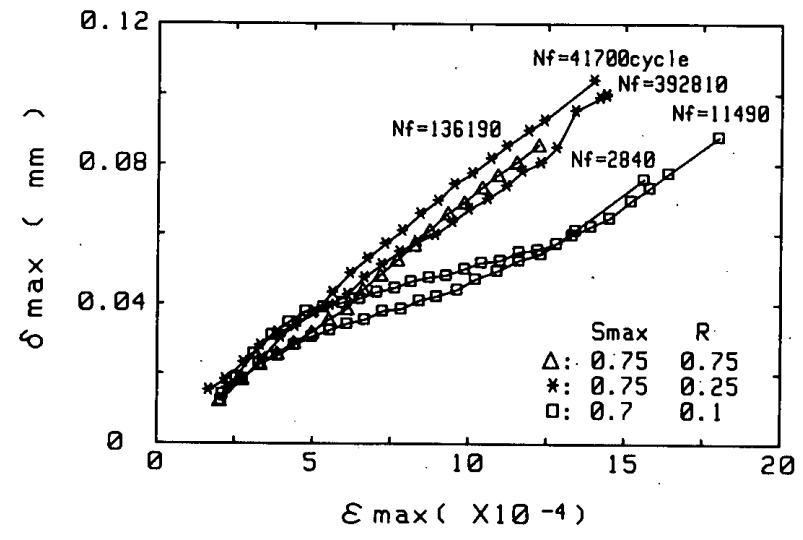

図一12 各繰返し上限応力下での開口変位と引張䋑ひずみ

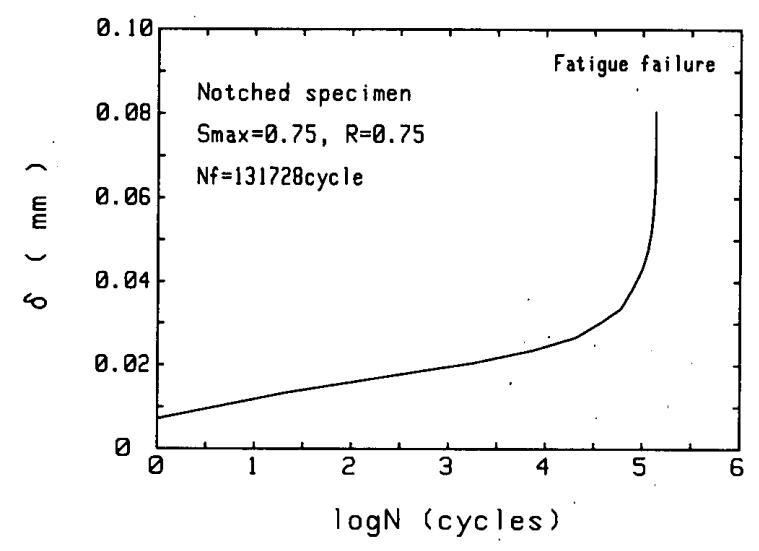

図一13 繰返し回数と最大開口変位量

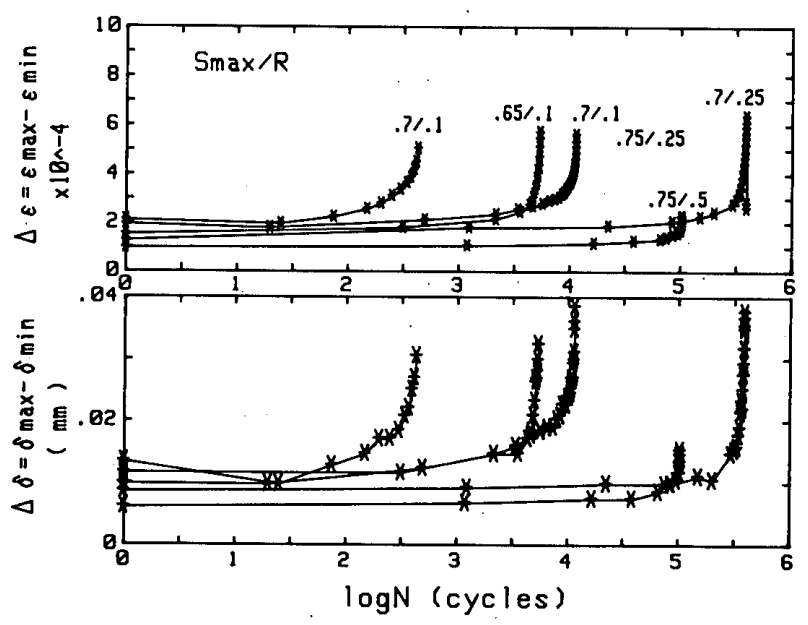

図一14 繰返し回数と引張縁ひすみ幅と開口変位幅

と安定成長に移り，最終的には龟裂が急速に進展して破 壊に至る。このような龟裂の進展速度を特徵づけるもの が「疲労破壊パラメータ」である。

亀裂進展の状態を把握するには，試験機の剛性が大き く影響するが，この状態をコンプライアンス $(\lambda)$ で評 価することもできる。すなわち，荷重 $(P)$ と開口変位 $(\mathrm{COD} ， \delta)$ との関係を式（9.) で示すごとができる。 コンプライアンスは, バネ定数の逆数である。

$$
\delta=\lambda \cdot P
$$

切欠き部から成長する亀裂の先端を明確に確認するこ とは困難であるので，本研究では次の方法を用いた。亀 


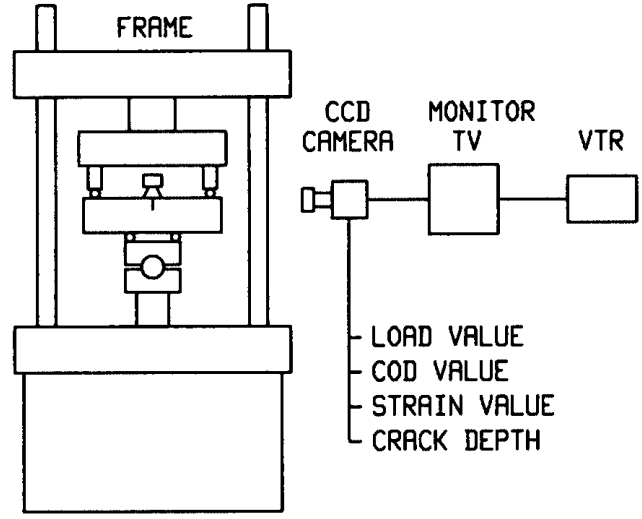

図一15 開口変位と亀裂深さ測定系

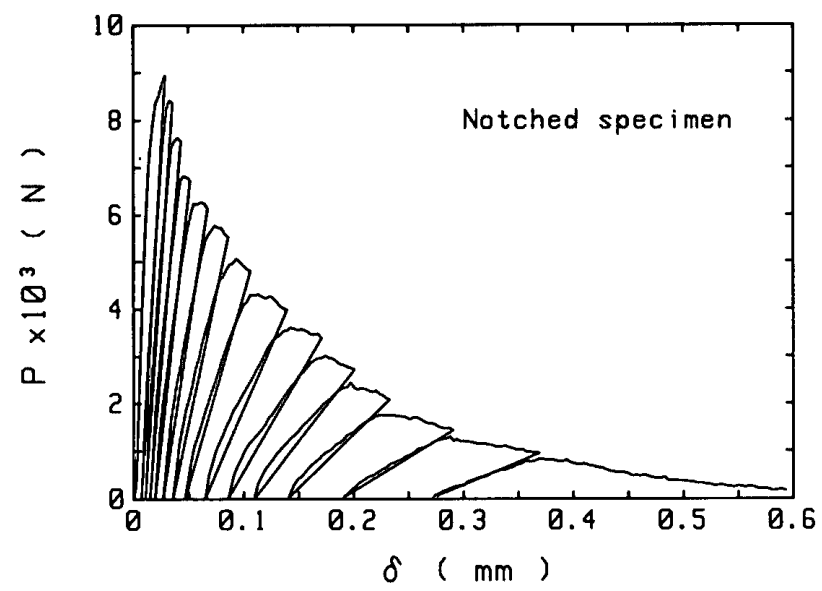

図一16 荷重と開口変位の曲線

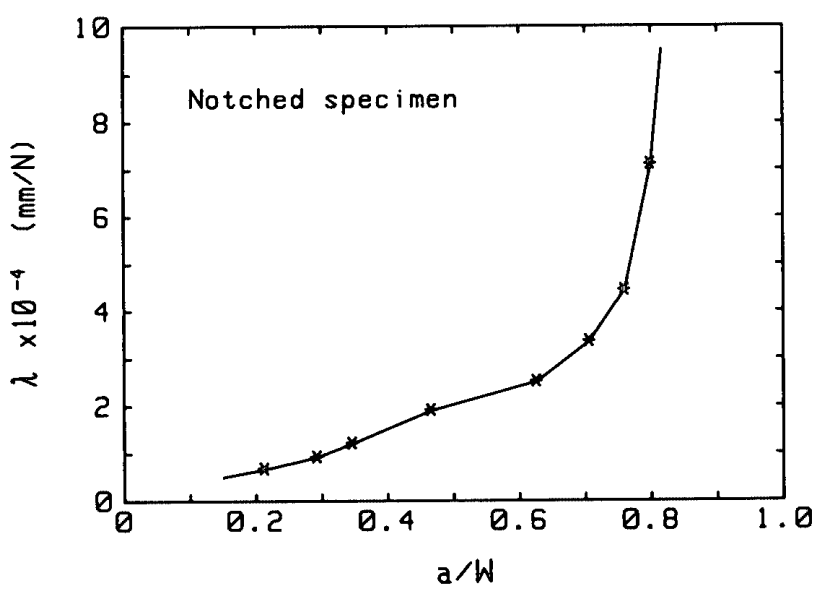

図一17 コンプライアンスと相対亀裂梁さ

裂長さとコンプライアンスとの関係を求める一手法とし $\tau$, CCD (Charge Coupled Device, 固体撮像素子, 30 万画素) カメラにより同一画面に画像入力する方法 をとった（図一15参照)。図一16は，切欠き材のコンプ ライアンスを求めるため, 梁の荷重と開口変位の関係を 示す。図ー17 は、コンプライアンスとこれに対応する 相対龟裂深さの実測関係をプロットした関係曲線であ る。

3.6 疲労亀裂進展速度と応力拡大係数幅

SEN 梁に関する繰返し応力下での亀裂長さ $(a)$ と

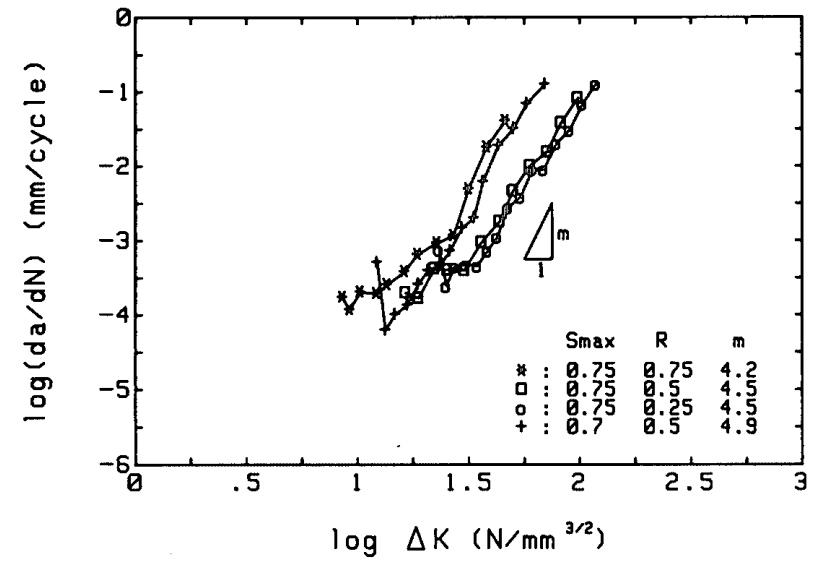

図一18 応力拡大係数幅と亀裂進展速度

繰返し数 $(N)$ の関係加, 疲労龟裂進展速度 $d a / d N$ を検討する。この進展速度の算定法には, セカント法や 増分多項式法などがあるが，簡便なセカント法によるこ とが多い。この方法は互いに隣接する 2 個のデー夕 $(n$ +1 回目之 $n$ 回目の繰返し回数の差に対する $n+1$ 回目 の亀裂長さの差) を直線で結び, その勾配値から $d a / d N$ を近似的に求めるものである。すなわち, 繰返 し応力が $\sigma_{\max }$ 之 $\sigma_{\min }$ の範囲 $(\Delta \sigma)$ で変動するとき, 応 力拡大係数も $K_{\max }$ と $K_{\min }$ の幅 $(\Delta K)$ で変動する。こ のときの平均龟裂長さ $\left(a_{\text {avr }}\right)$ 加ら近似的に応力拡大係 数幅を求めるものであり, 式（11）の関係に立脚する。

まず，疲労回数当たりの亀裂進展速度は式（10）で示 される。

$$
\frac{d a}{d N}=\frac{a_{n+1}-a_{n}}{N_{n+1}-N_{n}}
$$

応力拡大係数幅, $\Delta K$ は式（11）で示される。

$$
\Delta K=\Delta \sigma \cdot \sqrt{a_{\mathrm{avr}}} \cdot Y
$$

ここに,

$$
\begin{aligned}
& \Delta \sigma=\frac{3 \Delta P\left(L_{2}-L_{1}\right)}{2 B W^{2}} \\
& a_{\text {avr }}=\frac{a_{n+1}+a_{n}}{2} \\
& \Delta P=P_{\max }-P_{\min }
\end{aligned}
$$

なお，Yは式（3）で与えられる。ただし，式（3） の $\alpha$ の代わりに $\alpha=\frac{a_{\text {avr }}}{W}$ とする。

本実験で得られた $\Delta K$ と $d a / d N$ の関係の例を図一 18 に示す。この図は上限応力比 $S_{\max }=0.75$, 上下限応 力比 $R=0.25,0.5,0.75$ の疲労条件での $d a / d N$ と $\Delta K$ の関係を示す。 $\Delta K$ に対する切欠き先端の亀裂進展 速度 $d a / d N$ の変化の様子は, はじめ繰返し回数の增加 により除々に漸减（第 1 段階）し，ある繰返し回数で極 小となって亀裂進展が停滞する傾向を示す。これはコン クリートが載荷以前に存在する空妳・水隙や潜在クラッ クを内包しているために, 繰返し回数の増加の経過にお いて各部の欠陥周辺に生じた多数の不連続な亀裂発生と 


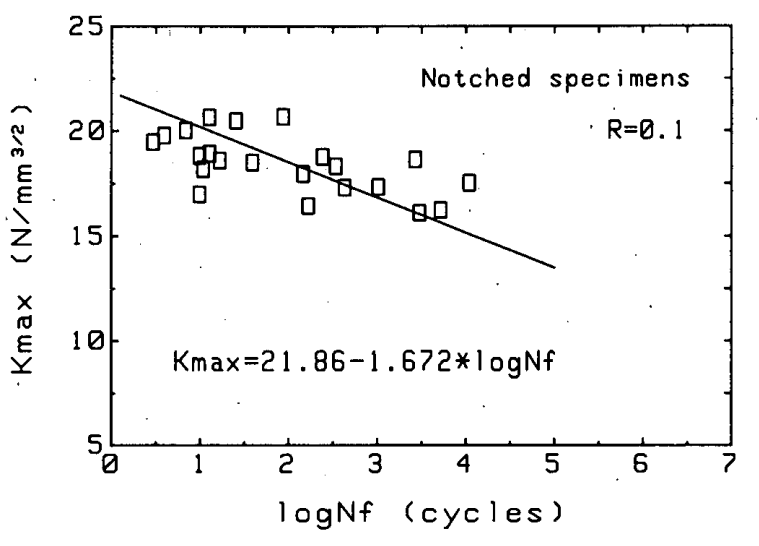

図一19 疲労破壊回数と限界応力拡大係数

分岐, および骨材の亀裂進展の阻止効果などの諸原因に より亀裂の成長を遅滞させるためと考えられる。この段 階を過ぎると亀裂進展速度は, 図上で值線的に安定成長 （第 2段階）の段階に入り, 漸増の状態になる。つまり, 図一18に示すように, 安定龟裂開始点から疲労破壊付 近まで一定勾配值 $m$ を示す。このように繰返し応力を 受けるコンクリートでは, 亀裂進展の過程は, 発生・潮 減・停滞・漸増の経過を経て, 破壊に至るものであり, 亀裂進展過程は一様一定ではない。

一般に, 疲労亀裂進展の速度 $d a / d N$ は応力拡大係数 幅 $\Delta K$ 之強い相関関係があり，両者は式（12）のべき 関数で表示される。この式は通常 Paris 則とよばれる。

$$
\begin{aligned}
& \frac{d a}{d N}=C(\Delta K)^{m} \ldots \ldots \ldots \ldots \ldots \ldots \ldots \ldots \ldots \ldots \\
& \log \left(\frac{d a}{d N}\right)=\log C+m \log (\Delta K)
\end{aligned}
$$

このようにしてコンクリートの疲労亀裂進展に対する 抵抗性は, $d a / d N$ と $\Delta K$ の関係で整理され, 勒性を反 映させることができる。この龟裂進展の特性は 2 つの領 域に区分することができる。つまり $\Delta K$ が小さい領域 では， $d a / d N$ が極小值を示す領域であり， $\Delta K$ が大き い領域では両対数図上で直線関係となり, 前記の式 (13) で表示される。この亀裂安定成長域での $d a / d N$ 亡 $\Delta K$ の関係を最小 2 乗法で求めた結果, 本実験のコンクリー トでは， $m=4.2 \sim 4.9$ の範囲にある。また $C$ は, $\log$ $C=-8.53 \sim-10.24$ の範囲にあった。つまり $C=2.99$ $\times 10^{-9} \sim 5.71 \times 10^{-11}$ である。

以上の結果から， $d a / d N$ は $R$ に依存しないことも確認 された。

\section{7 限界応力拡大係数之疲労破壊回数}

切欠き材の疲労強度について，一般に $S-N$ 関係を 用いて表示しているが，ここでは破壊力学上の考えを加 味して検討する。上限繰返し応力の限界応力拡大係数

$\left(K_{\max }\right)$ と疲労破壊回数の対数值 $\left(\log N_{f}\right)$ との関係を 求めた結果の例を図一19に示す。すなわち両関係は式 （14）で表し得る。

$$
K_{\max }=21.86-1.672 \cdot \log N_{f}
$$

$K_{\max }$ は, 亀裂先端の領域の応力状態を表しており, $N_{f}=0$ で $K_{\max }=21.86 \mathrm{~N} / \mathrm{mm}^{3 / 2}$ であり, $N_{f}=200$ 万回で は, $K_{\max }=11.3 \mathrm{~N} / \mathrm{mm}^{3 / 2}$ であった。すなわち, 限界応 力拡大係数は 200 万回疲労で約半減する。

\section{4. まとめ}

本研究におけるコンクリート梁の曲げ疲労試験の結果 から, 切欠き材と平滑材の疲労強度の比較, 疲労強度の 応力振幅依存性, 繰返し応力下の亀裂進展, 刍裂進展速 度に及ぼす疲労回数の影響などについて得られた知見は 以下のように結論ゔけられる。

1) 上下限応力比が $R=0.1$ のとき, 疲労強度の回帰式 は次式で与えられる。

切欠き材, $S_{\text {max }}=0.839-0.052 \cdot \log N_{f}$

平滑材, $S_{\text {max }}=0.89-0.051 \cdot \log N_{s}$

2) 切欠き材と平滑材の 200 万回曲げ疲労強度は, 静的 曲げ強度のそれぞれ 0.512 倍と 0.569 倍であり, また切 欠き材は平滑材よりも疲労強度は約 $10 \%$. 低い。

3）繰返し応力を受ける引張縁ひずみ幅と塑性ひずみ幅 の比は，切欠き材と平滑材で異なる。切欠き材は亀裂の 先端に応力が集中し，ひずみも增す。しかし平滑材は周 辺に存在する多くの欠宿にひずみが分散するため, 切欠 き材よりもひずみが小さくなると考えられる。

4) 曲げ疲労の亀裂進展過程は, 初期段階で漸减し, や がて停滞域をむかえ，その後漸増の経過をへて最後に急 激な進行により破壊に至る。

5）コンクリートの疲労亀裂進展速度と応力拡大係数幅 との間には, 安定亀裂の進展速度の領域つまり, ひずみ 軟化域で式 (12) のParis 則が成立する。

6) Paris 則で表示できる安定亀裂の進展速度 $(d a)$ $d N)$ は，絽返し応力比 $(R)$ に依存せず，ほぼ一定の 勾配を示す。この公配值 (定数) は, 本実験に用いたコ ンクリートで $m=4.2 \sim 4.9$ である。

7）切欠き材の限界応力拡大係数は， $R=0.1$ のときの 回帰式から, 200 万回疲労で $K_{\max }=21.86 \mathrm{~N} / \mathrm{mm}^{3 / 2}$ であ り，疲労前に対して值は半娍する。

\section{参考文献}

1) M. F. Kaplan : Crack Propagation and the Fracture of Concrete, Jour. of ACI pp. 591 609 Nov. 1961.

2) D. J. Naus and J. L. lott : Fracture Toughness of Portland Cement Concretes, ACI Jour. pp. $481 \sim 489$ Jun. 1969.

3) J. H. Brown: Measuring the fracture toughness of cement past and mortal, Mag. of Concrete Research, Vol. 24, No. 81 pp. 185 196. Dec. 1972.

4）岸谷孝一, 村上 聖, 平居孝之：コンクリートの破壊勒 性に関する研究，七メント技術年報 38, pp. 309 312, 
昭和 59 年.

5) 大岸佐吉, 小野博宣, 棚橋 勇, 山田兼義 : セメントペー スト・モルタルの破壊勒性に及ぼす空腙率の影響, 第 8 回コンクリート工学年次講演会論文集, pp. 345 348, 1986.

6) 三橋博三：コンクリートの破壞力学の現状と展望, コン クリート工学, Vol.25, No. 2, pp. 14 25, Feb. 1987.

7）六郷恵哲, 岩佐正徳, 鈴木泰生, 小柳 洽：各種コンクリー トの破壊力学バラメタ, コンクリート工学年次論文報告 集, Vol.11, No. 1, pp. 247 252, 1989.

8）古村福次郎, 阿部武雄, 篠原保二：ノッチ付きコンクリー 卜曲げ試験体の最大耐力後の軟化挙動に関する実験的研 究, セメント・コンクリート論文集, No. 43, pp. 298 303, 1989.

9) Stuart E. Swartz, Chen-Ming James and Kuo-Kuang Hu
: Crack Growth and Fracture in Plain Concrete-Static Versus Fatigue Loading, ACI Publication SP-75, pp. 47 —69, 1983.

10) M. H. Baluch, A. B. Qureshy and A. K. Azad : Fatigue Crack Propagation in Plain Concrete, SEM/RILEM International Conference on Fracture of Concrete and Rock, pp. 80 87, June 1987.

11) J.P. Lloyd, J. L. Lott and C.E. Kesler : Fatigue of Concrete, Univ. of Illinois Eng. Expt. Stn. Bulletin 499, 1968.

12) W. F. Brown, Jr and J.E. Srawley : Plane Strain Crack Toughness Testing of High Strength Metallic Materials, ASTM STP 410, 1966.

(1991 年 4 月 10 日原稿受理, 1991 年 8 月 9 日採用決定) 